\title{
Do customer profitability analyses pay? A survey of large Norwegian companies
}

\author{
Øyvind Helgesen* \\ Department of International Business, \\ NTNU in Aalesund, \\ Norwegian University of Science and Technology, \\ Larsgårdsvegen 2, 6009 Ålesund, Norway \\ Email: oyvind.helgesen@ntnu.no \\ *Corresponding author
}

\section{Helge Mykkeltveit Sandanger}

Finance and Controlling Department,

Dekkmann AS,

Breivollveien 31, 0668 Oslo, Norway

Email: helge.sandanger@gmail.com

\section{Joakim Sandbekk}

PricewaterhouseCoopers (PwC),

Dronning Eufemias Gate 8, 0191 Oslo, Norway

Email: joaksan@gmail.com

\begin{abstract}
The purpose of this paper is to study the relationships between the extents of use of customer profitability analyses (CPA) and business performance. In addition to CPA as an overall construct, five methods are included: 1) CPA of individual customers; 2) customer segments; 3) assessments of customer lifetime value; 4) valuations of customers; 5) customers as investments. A total of 437 large Norwegian companies were invited to answer a questionnaire, of which 171 participated giving a response rate of $39 \%$. CPA (overall construct) is positively linked to business performance. CPA of individual customers is the only method that significantly drives business performance. Thus, conducting detailed customer profitability analyses to establish reliable customer profitability accounts appears to be worth the effort. The respondents perceive the three forward-looking methods, i.e., (3), (4) and (5) as variations of one approach. Analogous studies are highly recommended. Cost estimation methods could also be addressed.
\end{abstract}

Keywords: business performance; customer accounting; CA; customer accounting profitability; CAP; customers as investments; customer profitability analyses; CPA; customer segments; customer lifetime value; Norway; valuation of customers.

Reference to this paper should be made as follows: Helgesen, $\varnothing$., Sandanger, H.M. and Sandbekk, J. (2018) 'Do customer profitability analyses pay? A survey of large Norwegian companies', Int. J. Managerial and Financial Accounting, Vol. 10, No. 4, pp.352-377. 
Biographical notes: Øyvind Helgesen obtained his Dr. Oecon. at the Norwegian School of Economics (NHH), Bergen, Norway. He is a Professor of Marketing and Management Accounting at the Department of International Business, Faculty of Economics and Management, NTNU in Ålesund, Norwegian University of Science and Technology. He has previously worked for different service sector companies, first as a Senior Business Advisor and later as the Director of Finance and Managing Director. His teaching, work and research interests relate to marketing subjects and management accounting. His papers have been published in a number of journals.

Helge Mykkeltveit Sandanger obtained his MSc in Economics and Business Administration, specialisation in management accounting. He is a Financial Controller in the Dekkmann AS, a Norwegian retail company within the tyre industry and a subsidiary of the German automotive manufacturing company, Continental AG.

Joakim Sandbekk obtained his MSc in Economics and Business Administration, specialisation in management accounting. He is a Senior Associate within the assurance business field of PricewaterhouseCoopers (PwC), a Norwegian auditing company belonging to the worldwide group of companies that are members of PricewaterhouseCoopers LLP.

\section{Introduction}

Customer profitability analyses (CPA) have received increasing attention during the last couple of decades both in scientific articles and in management accounting textbooks and teaching cases (Howell and Soucy, 1990; Foster and Gupta, 1994; Cooper and Kaplan, 1999; McManus and Guilding, 2008; Pollanen and Abdel-Maksoud, 2010; Atkinson et al., 2012; Datar and Rajan, 2018; Rickards and Ritsert, 2018). The use of this management accounting tool in industry has also been on the increase (Guilding and McManus, 2002; Lord et al., 2007; Havelin et al., 2013; Tanima and Bates, 2015). Presumably, greater insight into CPA figures should result in increased business performance. Thus, the obvious research question is whether the use of CPA is positively related to business performance or in other words: Do CPA pay?

The findings have been mixed. Malmi et al. (2004) found that the extent of use of CPA has no direct effect on business performance, while Bjørnenak (2013) found that the extent of use is positively related to return on equity (ROE) and is also favourable regarding the cost/income ratio, although this is not significant. McManus (2013) included three CPA-methods in the study:

1 CPA of individual customers

2 customer lifetime value (CLV) analysis

3 customer segment analysis.

McManus (2013) found no significant relationship between the extent of use of CPA and business performance. Al-Mawali et al. (2012) included three CPA-methods in the study:

1 CPA of individual customers 
2 CLV analysis

3 customer valuation and found that the extent of use of CPA of individual customers is positively linked to performance, particularly for larger companies (more than 300 employees).

Based on a literature review, this study has identified five CPA-methods:

1 CPA of individual customers

2 CPA of customer segments

3 assessments of CLV

4 valuations of customers

5 customers as investments.

The approach denoting customers as investments has not been included in any of the studies referred to above and none of the studies has included more than three customer account profitability (CAP)-methods. In addition, none of the studies has included an all-embracing variable that measures the extent of use of all relevant economic information relating to a customer or customer group. The purpose of this study is two-fold:

1 to analyse the relationship between an overall CAP-measure and business performance

2 to analyse the relationships between the extent of use of the five CAP-methods and business performance.

Thus, the paper addresses two levels: first, an overall level and next the method level. This is an empirical paper that aims to contribute by adding evidence. The context is large Norwegian companies taken from a register published each year, which gives an overview of the 500 largest Norwegian companies. Four hundred and thirty-seven companies were invited to answer a questionnaire, of which 171 participated giving a response rate of about $39 \%$.

The rest of the paper is organised as follows. A literature review forms the theoretical basis of the paper, followed by a discussion of the sample, data and method. The next section comprises the findings and the final section discusses these, addresses managerial implications, limitations and implications for further research and presents a conclusion.

\section{Literature and hypotheses}

\subsection{Business performances}

Business performance is described, defined and measured in various ways (Eccles, 1991; Neely et al., 1995; March and Sutton, 1997; Kaplan and Norton, 2004; Kirby, 2005; Richard et al., 2009; Giacosa et al., 2016; Vigolo et al., 2016). Studies may broadly be divided into two groups:

1 studies that analyse generic performance 
2 studies that examine economic and financial performance (Capasso et al., 2015).

Measures may be classified as financial or non-financial and objective or subjective (perceptual). The business performance concept may be perceived as consisting of two dimensions:

1 the description (definition) of the business scope that is measured

2 the method used for measuring business performance.

Regarding the business scope, Venkatraman and Ramanujam (1986) argue that three domains may be included. The narrowest domain contains the financial scope. Various financial indicators representing profitability, liquidity, etc. may be used to measure financial performance. Even if this approach is perceived as being rather narrow, financial performance measurements are the most used method when measuring business performance (Richard et al., 2009). The second domain broadens the business scope by including external and internal relationships, processes and activities, implying that nonfinancial indicators such as customer satisfaction, employee loyalty, learning climate, etc. are part of the measurement of business performance. The non-financial measures may be leading indicators of financial measures (Kaplan and Norton, 2004; Chenhall and Langfield-Smith, 2007; Silvi et al., 2015). The last of the three domains includes the previous ones with the addition of measures regarding multiple stakeholders (Neely and Adams, 2002). Although the latter domain - organisational effectiveness - is preferable, it is rather complex so the two first domains are the most used (Venkatraman and Ramanujam, 1986).

Business performance measurement can be classified into four common approaches. The first is the use of a single measure based on the belief that the measure is closely linked to business performance. Theory and evidence may support this belief, but it is often merely assumed (Richard et al., 2009). The second approach is the use of different dependent but identical independent variables and comparisons of the findings (see, e.g., Bjørnenak, 2013; Capasso et al., 2015). The third approach uses a number of indicators, both financial and non-financial, that are weighted, added and offered as a measure of business performance (Govindarajan, 1984; Gupta and Govindarajan, 1984; Govindarajan and Fisher, 1990). In the fourth approach, researchers aggregate dependent variables and assume convergent validity based on the correlations between the measures. This approach is most common with subjective measures of performance (Varadarajan and Ramanujam, 1990; Richard et al., 2009; Krishnan and Ramasamy, 2011; Vij and Bedi, 2016).

Regarding measurements of business performance, Richard et al. (2009, p.737) conclude that "these empirical findings suggest that researchers should not view the choice of subjective measures as a second-best alternative but, instead, should weigh the tradeoffs between subjective and objective measures against the research context to determine which is more favorable under the circumstances." Two approaches exist regarding perceptual measurements of business performance:

1 those that replicate objective measures (quasi-objective measures)

2 those that are fully subjective.

Self-reported perceptual measures allow researchers to address directly the business performance construct. 
This study measures business performance (organisational effectiveness) in accordance with the fourth measurement approach addressed above.

\subsection{Customer profitability analyses - a framework consisting of five methods}

In a distribution channel or value chain, there are customers at the various links from suppliers of raw material to consumers or end users. The various intermediaries (producers, wholesalers, etc.) have suppliers and customers. Some are suppliers to suppliers and others are customers of customers. Thus, the definition of the construct denoted 'customer' is not straightforward. However, with respect to customer profitability analyses, a customer is the direct buyer of products or services of a business (Helgesen, 2007; Ryals, 2008).

Various customer profitability analyses exist. Based on a review of literature, five methods are included in this study:

1 profitability analyses of individual customers

2 profitability analyses of customer segments

3 assessments of CLV

4 valuations of customers

5 customers as investments.

In addition, CPA as a holistic notion is briefly addressed.

\subsubsection{Customer profitability analyses of individual customers}

Customer profitability analyses (CPA) "involves calculating profit earned from a specific customer", implying that "the profit calculation is based on costs and sales that can be traced to a particular customer" [Guilding and McManus, (2002), p.46]. This method is sometimes referred to as CAP (Connolly and Ashworth, 1994; Foster et al., 1996) or simply CA (Nira et al., 2001; Weir, 2008; Fish et al., 2017).

CPA of individual customers estimates the customer results (profits) based on historical data of revenues and costs for one or more periods, such as the previous month or year. The analyses may be elaborated ad hoc or as part of the ongoing management accounting system of a business unit (Helgesen, 2007). Customer revenues are the sum of incomes for the given time period. Customer costs fall into three categories:

1 the costs of providing goods or services

2 the costs of service (marketing, sales, customer service, etc.)

3 customer-specific overheads (where relevant) (Ryals, 2008).

More detailed approaches are available (van Raaij et al., 2003; Horngren et al., 2012; Bjørnenak and Helgesen, 2013). In order to trace costs, it is necessary to go into details. This implies the need to study all the accounts, all vouchers and all items in the bookkeeping system. This method has a bottom-up approach.

When establishing reliable profitability figures for customer accounts many aspects have to be considered (Storbacka, 1995; Noone and Griffin, 1999; Kaplan and Anderson, 
2004, 2007). For instance, customer accounts can be established by using different estimation methods:

1 full costing

2 variable costing

3 activity-based costing (ABC)

4 time-driven (or capacity-driven) activity-based costing (TDABC).

These methods will of course tend to result in different designs of the specified accounts. However, the most important aspect to remember is that different approaches result in different estimates of customer profitability. TDABC gives the most detailed approach and appears to be very useful with respect to customer profitability analyses of individual customers (Kaplan and Anderson, 2004; Everaert et al., 2008; Demeere et al., 2009). Thus, individual customer profitability analyses may provide detailed and reliable CAP figures.

Customer profitability accounts can be part of a market hierarchy consisting for instance of orders, customers, markets and business units (Helgesen, 2007). The assignment of costs is then linked to the various levels of the market hierarchy that reflects a market-oriented accounting framework.

\subsubsection{Customer segment profitability analyses}

While CAPs of individual customers have a bottom-up approach, customer segment profitability analyses usually have a top-down approach. The profitability object is now the individual customer segment and not the individual customer (Ryals, 2008). Various characteristics are used as segmentation variables for both consumer and business markets (Helgesen, 2006). For consumer markets, the types of segmentation most often used are based on variables related to geographical, demographic, psychographic and behavioural characteristics. For business markets, additional types of segmentation have been introduced, for example, based on industry sector, buying process characteristics (e.g., formality), structure of procurement or buyer-seller relationships.

The top-down method starts from the total customer-base and establishes revenue and cost figures for the customer segments (groups). "The logic underpinning this approach is that customer groups are more important than individual customers so overhead costs are traced to customer segments and customers are best treated as aggregated groups" [Lind and Strømsten, (2006), p.1258]. When indirect costs (fixed costs) represent a large proportion of the total costs, a top-down approach may result in unreliable cost allocation to the customer segments (Howell and Soucy, 1990; Ryals, 2008). Thus, customer segment profitability reports may be unreliable. In addition, the analyses do not give insight into the customer profitability of individual customers except for conclusions that might be drawn based on the average figures of customer segments.

Customer segment profitability reports may also be established based on customer profitability analyses of individual customers. When detailed information is available, this may be aggregated in different ways (Helgesen, 2006, 2008).

Customer profitability analyses and customer segment profitability analyses focus on past revenue and cost figures. Thus, there are limitations to customer profitability figures 
that reduce their usefulness for decision-making. The past may not be a good guide to the future.

\subsubsection{Customer lifetime value}

When measuring CLV, the focus is on each customer and future cash flows. CLV may be calculated as the net present value of future cash flows (Berger and Nasr, 1998; Kumar, 2008; Farris et al., 2010). "Customer lifetime value is the expected value of the future relationship with that customer" [Ryals, (2008), p.87].

A number of CLV methods are available (Gupta and Lehmann, 2005; Kumar, 2008; Rust et al., 2011; Holm et al., 2012). When estimating CLV, at least the following information is needed:

1 the remaining customer life time (time horizon, e.g., in years)

2 the net cash flow for these years, i.e., in and outgoing payments

3 the cost of capital.

Risks such as credit risks may also be included (Helgesen, 2008; Brodtkorb, 2014).

The customer profitability may change over time (Foster and Gupta, 1994; Ryals, 2008). Reichheld (1996) suggests four reasons for keeping customers over time:

1 revenues from customers typically grow over time

2 it is usually more efficient to serve existing customers than new customers

3 old customers may pay higher prices than new ones

4 satisfied customers may act as referrals who recommend the business to others.

This last argument is further addressed in the next section.

\subsubsection{Customer valuations}

Customers may add value to a business in ways other than the financial value they bring through their CLV (Foster and Gupta, 1994; Guilding and McManus, 2002; Kumar, 2018). "Valuation of customers or customer groups as assets refers to the calculation of the value of customers to the company" [Guilding and McManus, (2002), p.48]. In addition to 'customer value (CV)', this approach has been denoted 'strategic value' (van Raaij, 2005), 'relational value' (Ryals, 2008) and 'customer equity' (Tanima and Bates, 2015; Nenonen and Storbacka, 2016). When assessing the CV, externalities should be evaluated (Helgesen, 1999). External effects relate to the consequences of an action by one entity or group of entities as they have an impact on others. This implies that the customer relationship explicitly or implicitly influences the cash flow of other customers' relationships with the business unit. External effects may be positive or negative, implying that the 'real' CV may be higher or lower than the CLV.

Various externalities (or indirect value drivers) have been addressed such as attraction, learning, influence and volume (van Raaij, 2005; Kumar, 2018). Attraction may be split into references and referrals (Ryals, 2008). Some well-known customers can serve as references for the acquisition of new customers and some customers may speak positively and thus act as advocates for the business (Helm and Salminen, 2010; Jalkala and Salminen, 2010). According to Ryals (2008), learning and innovation may include 
shared information, process innovation, product testing and benchmarking. Thus, learning and innovation may increase revenues and/or reduce costs for the company. Kumar asserts that some customers may 'influence on prospects' and other customers' purchases' [Kumar, (2018), p.6]. According to van Raaij (2005, p.380), some customers can, owing to volume, "absorb large amounts of fixed costs, thus enabling the company to engage in profitable activities with other customers."

\subsubsection{Customers as investments}

The two first approaches addressed ('CAP of individual customers' and 'customer segment profitability analyses') have a retrospective approach and the next two ('CLV' and 'customer valuation') a prospective approach. 'Customer as investments' combines these perspectives. Thus, this method focuses on the whole lifetime of a customer relationship (i.e., 'from the cradle to the grave').

The net present value of a customer (or a customer segment) consists of the sum of two parts:

1 the net present value of past periods

2 the net present value of expected cash flows in the future.

Estimations can be carried out in various ways (Rust et al., 2000; Gupta and Lehmann, 2005; Kumar, 2008). Often, the net present value may be negative in the beginning of a relationship, however, may change sign over time (Reinartz and Kumar, 2000; Irvine et al., 2016). This is often the situation in business-to-business relationships, but is also relevant for the private sector, e.g., the banking sector (Reichheld, 1996). These 'investments' are usually denoted acquisition costs and are often compared with retention costs of customers. Insight into acquisition and retention costs may help decision makers to achieve customer profitability (Reinartz et al., 2005; Egan, 2008).

Calculations may be carried out both for customer segments and individual customer. Insight regarding the past may be useful with respect to the customer management for the coming periods, for example by establishing budgets for each of the customer accounts (Helgesen, 2007).

\subsubsection{CPA as a holistic notion}

Above five CPA-methods have been briefly addressed. The subject is rather 'new' and there is no 'consensus' regarding the content of all the methods, particularly the last three approaches. Thus, an over-arching construct that intends to define the subject area is included. This holistic notion may be looked upon as "the process of identifying, measuring, communicating and reporting economic information relating to a customer or customer group" [McManus, (2013), p.140]. This "includes all accounting practices towards appraising profit, sales, or present value earnings relating to a customer or group of customers" [Guilding and McManus, (2002), p.48].

\subsection{Former studies connecting CPA-methods and performances}

Some studies have addressed the extent of use of CPA as one of a number of management accounting tools. Other studies have analysed the relationships between the 
extent of use and the usefulness of CPA-methods and some studies (rather few) have addressed the relationship between the extent of use of CPA and business performance. The findings of this study are compared with the findings of four former studies: Malmi et al. (2004), Al-Mawali et al. (2012), McManus (2013) and Bjørnenak (2013). The contexts of these studies are businesses in Finland, Jordan, Australia and Norway.

Malmi et al. (2004) studied the relationships between CPA, customer orientation and business unit performance in Finland. The purpose of the study was two-fold, i.e., to explain whether an organisation's customer relationship management (CRM) orientation had an impact on the form and the extent of use of CPA and to examine the relationships between a company's CRM orientation, CPA practices and business unit performance. About 1,600 companies were contacted, i.e., about $25 \%$ of all Finnish companies that had at least 100 employees. The final sample consisted of 354 companies, giving a response rate of about $22 \%$. The findings suggest that CRM orientation has a direct effect on business performance. The extent of use of CPA has no direct effect on business performance, but moderates positively the relationship between CRM orientation and performance. Thus, CPA practices support companies' efforts to improve their performance with CRM.

Al-Mawali et al. (2012) addressed the relationship between CPA information usage and organisational performance. Three CPA methods were included and measured using a number of statements on a seven-point Likert scale:

1 CPA of individual customers (six items)

2 CLV analysis (six items)

3 customer valuation (five items).

Seven items measured organisational performance. Each respondent was asked to evaluate the company's performance level by comparison with the major competitor on four financial and three non-financial measures on a seven-point Likert scale $(1=$ poor and $7=$ excellent). The following financial measures were included:

1 ROE

2 return on investment

3 sales growth rate

4 operating profit.

The following non-financial measures were included:

1 customer satisfaction rate

2 market share rate

3 new service success rate.

The context is service companies listed on Amman Stock Exchange 2009, i.e., 192 companies. The sample represents $55.2 \%$ of this population (sample frame). Regression analyses including the three CPA-methods as well as two control variables (firm size and industry type) indicate that 'CPA of individual customers' and 'firm size' 
are significant drivers of 'organisational performance', particularly for larger companies (more than 300 employees).

McManus (2013) provides the results of a study of the Australian hotel industry. The sample consists of 165 hotels representing $33.0 \%$ of the sample frame (500 hotels). Items (statements) were measured on a seven-point Likert scale. Three CPA-methods were included and measured by a number of items:

1 CPA of individual customers (three items)

2 CLV analysis (six items)

3 customer segment analysis (three items).

Business performance was measured by an adapted version of an instrument developed by Govindarajan (1988) and Govindarajan and Fisher (1990), i.e.:

1 financial performance (four items)

2 non-financial performance (two items).

The study included four antecedents (competition intensity, perceived environmental uncertainty, structure and strategy) and two control variables (market orientation and size). The study found significant relationships between antecedents/control variables and the extent of use of CA-methods, however no significant relationship between the extent of use of CA-methods and business performance.

Bjørnenak (2013) focuses on Norwegian banks and the extent of their use of budgets, however the study also includes some other management accounting tools. One hundred and eighteen banks were invited to answer a questionnaire of which 81 participated (68.6\%). Data were collected on three issues:

1 the use and perceived usefulness of different management accounting tools, including budgets, benchmarking, $\mathrm{ABC}$, balanced scorecards, rolling forecasts and CPA

2 the degree to which respondents agreed with 18 different statements dealing with budgeting critiques

3 measures of performance.

Regarding business performance, two financial measures are included:

1 ROE

2 the cost/income ratio.

These financial measures are among the most used in this industry. The extent of use of the management tools included was measured on a five-point Likert scale. Together with firm size (control variable), the six management tools were included as independent variables in regression analyses (OLS) where ROE and the cost/income ratio were dependent variables. Customer profitability analyses are positively related to ROE. The extent of use of customer profitability analyses is also favourable with respect to the cost/income ratio; however, the coefficient estimate is not significant. 


\subsection{Models and hypotheses}

Former studies addressing relationships between the extent of use of CPA and business performance have included four of the five CPA-methods discussed in the literature above: CPA of individual customers, customer segment profitability analyses, CLV and customer valuation. The approach denoting customers as investments has not been included in any of the studies referred to and none of these has included more than three CAP-methods. In addition, none has included an all-embracing or overall variable that measures the extent of use of all relevant economic information relating to customers or customer groups.

In this study, two levels of customer profitability analyses are addressed, first an overall level and next the method level. This is illustrated in Figure 1. Model 1 addresses 'customer accounting as a holistic notion', i.e., an over-arching construct. Model 2 addresses the five CAP-methods. In both models, business sizes (revenues) and two categories of respondents [chief financial officer (CFO) or other categories of respondents] are included as control variables (Chenhall and Langfield-Smith, 2007).

Figure 1 Concepts and relationships

\begin{tabular}{|l|l|}
\hline Model 1 (level 1): \\
(1) Customer accounting as holistic notion \\
(2) Revenues (business size) \\
(3) CFO - other respondents ('dummy') \\
\hline Model 2 (level 2): \\
(1) Customer profitability analyses of \\
individual customers \\
(2) Customer segment profitability analyses \\
(3) Customer lifetime value \\
(4) Customer valuation \\
(5) Customers as investments \\
(6) Revenues (business size) \\
(7) CFO - other respondents ('dummy')
\end{tabular}

Previous studies provide mixed results regarding the relationship between the extent of use of CPA and business performance; however, three of the four studies addressed above point to a positive association. Similar results have been found when addressing the relationship between the use of accounting information and organisational performance, a relationship that has been subjected to extensive empirical examination (Baines and Langfield-Smith, 2003; Cadez and Guilding, 2008; Al-Mawali et al., 2012). A majority of studies indicate a positive relationship between the use of accounting information and business performance. In addition, normative accounting theory suggests that once you calculate correctly, you make the right decisions (Cooper and Kaplan, 1988). This implies that the usage of CAP-information should give insight into making decisions regarding customers, thus resulting in superior business performance. These arguments have motivated the current study to propose the following hypotheses:

H1 Overall, there is a positive relationship between the extents of use of holistic customer profitability analyses and business performance. 
H2 The use of profitability analyses as seen in

a the customer profitability analyses of individual customers

b profitability analyses of customer segments

c analyses of CLV

d valuations of customers

e analyses of customers as investments, is positively related to business performance.

Thus, the expectation is to find positive relationships between customer profitability analyses and business performance both for the holistic notion and for the five CAP-methods included.

\section{Context, sample and methodology}

The context of this study is large Norwegian companies taken from a register (list) that gives an overview of the 500 largest Norwegian companies based on revenues. Such overviews are published each year. Owing to the fact that the focus is on customer profitability analyses, some companies were excluded (health companies, holding companies, etc.). Thus, the revised list consisted of 437 companies (sample frame). All these companies were contacted and invited to participate in the project.

Table 1 The sample profile

\begin{tabular}{lcccc}
\hline Section & Title & $\begin{array}{c}\text { Number of } \\
\text { respondents }\end{array}$ & $\begin{array}{c}\text { In \% of the } \\
\text { sample }\end{array}$ & $\begin{array}{c}\text { The distribution of } \\
\text { the sample frame } \\
\text { (population) }\end{array}$ \\
\hline $\mathrm{C}$ & Manufacturing & 24 & 14.0 & 17.6 \\
$\mathrm{D}$ & Electricity, gas, steam and air & conditioning supply & & 6.4 \\
F & Construction & & 5.3 & 7.3 \\
$\mathrm{G}$ & Wholesale and retail trade & 34 & 10.5 & 21.5 \\
$\mathrm{H}$ & Transportation and storage & 10 & 5.8 & 6.9 \\
$\mathrm{I}$ & Accommodation and food service & 24 & 14.0 & 14.9 \\
& activities & & & \\
$\mathrm{J}$ & Information and communication & 11 & 6.4 & 2.3 \\
$\mathrm{~K}$ & Financial and insurance activities & 18 & 10.5 & 11.9 \\
$\mathrm{~L}$ & Real estate activities & 3 & 1.8 & 2.5 \\
& Other economic activities & 20 & 11.7 & 8.7 \\
& Sum & 171 & 100.0 & 100.0 \\
\hline
\end{tabular}

A total of 171 questionnaires were answered, representing a response rate of $39 \%$. Table 1 presents the sample profile based on NACE, the Statistical Classification of Economic Activities in the European Community (Eurostat, 2008). The companies are from 15 different industries of which nine are specified and the remaining ones grouped together. Table 1 presents the number of companies within each of the economic sections, the proportions they represent with respect to the sample (171 companies) and 
the distribution of the sample frame (437 companies). The composition of the sample largely corresponds with the composition of the sample frame. Thus, one cannot assert that the sample is not representative of the sample frame (population).

CFOs of the companies were the most frequent respondents (76\%). However, all the other respondents also represented the top management teams of the companies, suggesting that all the respondents had perfect insight into the subject area of this paper. According to information from the questionnaires, the yearly revenues were on average about NOK 5.7 billions. Table 2 (part A) gives descriptive statistics of the revenues $(\mathrm{n}=170)$ showing that the differences are huge.

Table 2 The sample - descriptive statistics (part A and part B) and correlation coefficients (part B)

\begin{tabular}{|c|c|c|c|c|c|c|c|c|}
\hline \multicolumn{2}{|c|}{ Variable } & \multirow{2}{*}{$\frac{\text { Mean }}{5,691.4}$} & \multirow{2}{*}{$\frac{S D}{11,553.1}$} & \multirow{2}{*}{$\frac{\text { Skewness }}{4.24}$} & \multirow{2}{*}{$\frac{\text { Kurtosis }}{20.13}$} & \multirow[t]{2}{*}{1} & \multirow[t]{2}{*}{2} & \multirow[t]{2}{*}{3} \\
\hline Part A & $\begin{array}{l}\text { Sales revenues of the } \\
\text { sample }(n=170)\end{array}$ & & & & & & & \\
\hline \multirow[t]{4}{*}{ Part B } & $\begin{array}{l}\text { Some financial key } \\
\text { measures }(\mathrm{n}=171)\end{array}$ & & & & & & & \\
\hline & $\begin{array}{l}1 \text { Average increase in } \\
\text { turnover (IIT) the last } \\
\text { three years (in \%) }\end{array}$ & 7.19 & 9.38 & 2.15 & 9.83 & 1.00 & & \\
\hline & $\begin{array}{l}2 \text { Average return on } \\
\text { assets (ROS) the last } \\
\text { three years (in \%) }\end{array}$ & 9.24 & 9.74 & 2.57 & 9.57 & $.27 *$ & 1.00 & \\
\hline & $\begin{array}{l}3 \text { Average return on } \\
\text { assets (ROA) the last } \\
\text { three years (in \%) }\end{array}$ & 10.72 & 8.99 & 1.05 & 1.11 & .11 & $.33 * *$ & 1.00 \\
\hline
\end{tabular}

Note: $* * \mathrm{p}<.01$ and $* \mathrm{p}<.05$.

The questionnaire briefly addressed the purpose of the study and explained all the concepts before addressing questions. Thus, concepts such as 'customer profitability analyses of individual customers' and 'customer segment profitability analyses' were defined before questions were asked. Business performance was measured as a perceptual variable based on four items in the questionnaire. "Please indicate how you perceive your business has performed:

1 compared to your industry average over the last three years

2 compared to your closest competitors over the last three years

3 compared to your expectations over the last three years

4 over the last three years based on a total appraisement."

The respondents are supposedly well-informed respondents (CFOs) with sufficient insight to evaluate subjectively the overall performance of the business (organisation). Financial key measures validate the findings. Except for performance measurements, all the perceptual items of the questionnaire were measured on a Likert-scale from ' 1 ' to ' 7 ', where ' 1 ' represented the lowest level and ' 7 ' the highest level. Regarding performance measurements a seven-point semantic differential scale was used from ' -3 ' (well below average) to ' +3 ' (well above average). 


\section{Findings}

\subsection{Business performances}

Table 3 shows descriptive statistics of the four variables that measure business performance as well as correlation coefficients among them. A confirmatory factor analysis of the four items resulted in one factor. Variance extracted was $79.2 \%$. Cronbach's alpha is 0.91 and could be increased to .93 if the item measuring 'performance compared to expectations' is excluded. However, all the four variables are included in a new variable that is established as a summated scale. This new variable is denoted 'perceived business performance' (PBP).

Table $3 \quad$ PBP - descriptive statistics and correlation coefficients $(n=171)$

\begin{tabular}{|c|c|c|c|c|c|c|c|c|c|c|}
\hline \multicolumn{2}{|c|}{ Variable } & \multirow{2}{*}{$\frac{\text { Mean }}{.85}$} & \multirow{2}{*}{$\frac{S D}{1.17}$} & \multirow{2}{*}{$\frac{\text { Skewness }}{-.34}$} & \multirow{2}{*}{$\begin{array}{c}\text { Kurtosis } \\
-.11\end{array}$} & \multirow{2}{*}{$\frac{1}{1.00}$} & \multirow[t]{2}{*}{2} & \multirow[t]{2}{*}{3} & \multirow[t]{2}{*}{4} & \multirow[t]{2}{*}{5} \\
\hline 1 & $\begin{array}{l}\text { Compared to your } \\
\text { industry average }\end{array}$ & & & & & & & & & \\
\hline 2 & $\begin{array}{l}\text { Compared to your } \\
\text { closest } \\
\text { competitors }\end{array}$ & .77 & 1.21 & -.19 & -.13 & $.76 * * *$ & 1.00 & & & \\
\hline 3 & $\begin{array}{l}\text { Compared to your } \\
\text { expectations }\end{array}$ & .22 & 1.21 & -.16 & -.25 & $.59 * * *$ & $.58 * * *$ & 1.00 & & \\
\hline 4 & $\begin{array}{l}\text { Based on a total } \\
\text { appraisement }\end{array}$ & .77 & 1.20 & -.58 & .30 & $.84 * * *$ & $.82 * * *$ & $.73 * * *$ & 1.00 & \\
\hline 5 & $\begin{array}{l}\text { Perceived } \\
\text { business } \\
\text { performance } \\
(\mathrm{PBP})\end{array}$ & .65 & 1.06 & -.39 & .29 & $.90 * * *$ & $.89 * * *$ & $.82 * * *$ & $.95 * * *$ & 1.00 \\
\hline
\end{tabular}

Note: $* * * \mathrm{p}<.001$.

For validation purposes, three financial measures furnished by the respondents are used, i.e.:

1 average increase in turnover (IIT) (sales) over the last three years

2 average return on sales (ROS) over the last three years

3 average return of assets (ROA) over the last three years.

All three measures are expressed in percentages. Table 2 part B presents descriptive statistics of the three variables as well as correlation coefficients among them. The correlation coefficients are as follows regarding the relationships between the new variable denoted 'PBP' and the three financial measures: $r$ (PBP, IIT $)=.30(p<0.001$, $\mathrm{n}=114), \mathrm{r}(\mathrm{PBP}, \mathrm{ROS})=.33(\mathrm{p}<0.001, \mathrm{n}=95)$ and $\mathrm{r}(\mathrm{PBP}, \mathrm{ROA})=.41(\mathrm{p}<0.001$, $\mathrm{n}=95)$. According to Cohen (1988), all the three correlation coefficients are medium sized. The findings are in accordance with former studies (Richard et al., 2009). The variable 'PBP' (summated scale) represents the dependent variable of the study's models. 


\subsection{The extents of use of customer profitability analyses}

Regarding the use of customer profitability analyses, the respondents were initially asked about the extent of use of customer profitability analyses (CPA) as a total appraisal (holistic notion): "Please, indicate the extent of use of customer profitability analyses the last three years." In the heading of the question, it was underscored that the question was meant to embrace all kinds of CPA. Later on in the questionnaire, the five CPA-methods were briefly described in accordance with the discussion in Section 2.2. Next, the following questions were asked: "Please indicate to what extent the following CPA-techniques have been used during the last three years:

1 CPA of individual customers

2 profitability analysis of customer segments

3 customer life-time value

4 customer valuation

5 customers as investments."

Table 4 part A presents the findings regarding the extents of use of customer profitability analyses both as a total appraisal and at the method-level. It seems that customer segment profitability analyses are more used than customer profitability analyses of individual customers. The remaining three methods (CLV analyses, customer valuation and customers as investments) seem to be less used than profitability analyses of individual customers.

Table 4 The use of customer profitability analyses (part A), inclusive control questions (part B) - descriptive statistics $(\mathrm{n}=171)$

\begin{tabular}{|c|c|c|c|c|c|}
\hline \multicolumn{2}{|c|}{ Variable } & Mean & $S D$ & Skewness & Kurtosis \\
\hline \multicolumn{6}{|c|}{ Use (part A) } \\
\hline TA & Based on a total appraisement & 4.41 & 1.58 & -.19 & -.87 \\
\hline 1 & $\begin{array}{l}\text { Customer profitability analyses of individual } \\
\text { customers }\end{array}$ & 4.16 & 1.97 & -.18 & -1.20 \\
\hline 2 & Profitability analyses of customer segments & 4.50 & 1.72 & -.40 & -.79 \\
\hline 3 & Customer life-time value analyses & 2.48 & 1.63 & .88 & -.24 \\
\hline 4 & Customer value assessments & 2.41 & 1.58 & .99 & .07 \\
\hline 5 & Customers as investments & 2.03 & 1.37 & 1.29 & .88 \\
\hline \multicolumn{6}{|c|}{ Control (validation) questions (part B) } \\
\hline 6 & $\begin{array}{l}\text { The basis of our CPA is individual customer } \\
\text { profitability analyses }\end{array}$ & 3.98 & 1.96 & -.16 & -1.25 \\
\hline 7 & $\begin{array}{l}\text { Our CPA is solely based on calculations of } \\
\text { customer segments }\end{array}$ & 4.05 & 1.78 & -.23 & -1.06 \\
\hline 8 & $\begin{array}{l}\text { When doing CPA, we use net present value } \\
\text { calculations }\end{array}$ & 2.55 & 1.73 & .86 & -.43 \\
\hline 9 & When doing CPA, we also include external effects & 3.05 & 1.67 & .22 & -1.20 \\
\hline 10 & $\begin{array}{l}\text { When doing CPA, we consider both the past and } \\
\text { the future }\end{array}$ & 3.28 & 1.96 & .35 & -1.18 \\
\hline
\end{tabular}




\subsection{A closer look at the five customer profitability analyses methods}

In order to validate the findings with respect to the extents of use of the various CAP-methods, five additional questions were included in the questionnaire. The respondents were asked to express their degree of agreements with respect to five statements:

1 The basis of our CPA is individual customer profitability analyses.

2 Our CPA is solely based on calculations of customer segments.

3 When doing CPA, we use net present value calculations.

4 When doing CPA, we also include external effects.

5 When doing CPA, we consider both the past and the future.

Table 4 part B presents descriptive statistics of the variables (items) included for validation purposes.

Table 5 presents the correlation coefficients among the ten variables. The coefficients are rather large between the variables measuring each of the concepts and the variables included for validation purposes, i.e., 1 and 6, 2 and 7, etc. The highest coefficient is 0.61 and lowest is 0.35 . All coefficients are significant at the 0.001 level. Thus, these findings contribute to a validation of the measurements.

Table 5 Correlations coefficients among variables measuring and validating customer profitability analyses methods $(\mathrm{n}=171)$

\begin{tabular}{ccccccccccc}
\hline & 1 & 2 & 3 & 4 & 5 & 6 & 7 & 8 & 9 & 10 \\
\hline 1 & 1.00 & & & & & & & & & \\
2 & $.31 * * *$ & 1.00 & & & & & & & & \\
3 & $.26 * * *$ & .12 & 1.00 & & & & & & & \\
4 & $.31 * * *$ & .13 & $.45^{* * *}$ & 1.00 & & & & & & \\
5 & $.19^{*}$ & .07 & $.51^{* * *}$ & $.56^{* * *}$ & 1.00 & & & & & \\
6 & $.61 * * *$ & $.20 * *$ & $.22 * *$ & $.24 * * *$ & $.19 *$ & 1.00 & & & & \\
7 & $-.24 * *$ & $.35^{* * *}$ & -.06 & .04 & -0.5 & -.13 & 1.00 & & & \\
8 & .08 & $.16^{*}$ & $.49 * * *$ & $.38^{* * *}$ & $.41 * * *$ & .14 & 0.06 & 1.00 & & \\
9 & .06 & .12 & $.32 * * *$ & $.38^{* * *}$ & $.35 * * *$ & .10 & 0.09 & $0.40 * * *$ & 1.00 & \\
10 & $.18 *$ & .10 & $.32 * * *$ & $.42 * * *$ & $.37 * * *$ & -0.02 & 0.09 & $0.28 * * *$ & $0.45 * * *$ & 1.00 \\
\hline
\end{tabular}

Note: $* * * \mathrm{p}<.001 ; * \mathrm{p}<.01 ; * \mathrm{p}<.05$.

Regarding the three methods denoted CLV, customer valuation and customers as investments, Table 5 presents 15 correlation coefficients, i.e., both among the variables measuring the concepts and the control variables. All coefficients are significant at the 0.001 level. Thus, it seems that these three methods are closely linked together.

A factor analysis based on all the five use variables, extracts two factors. Method 2 (profitability analyses of customer segments) represents one factor and methods 3-5 another factor, while method 1 (customer profitability analyses of individual customers) is related to both factors; however, for this method the two factor loadings are rather low. A three-factor solution brings nothing new. Thus, the three methods (3-5) seem to 
measure one construct according to the respondents' perceptions. One factor is extracted when doing a factor analysis of the three variables. Of the variance, $67.1 \%$ is extracted. Cronbach's alpha is 0.75 and is reduced if one of the items is excluded. Thus, a new variable is established as a summated scale of the three variables. This new variable is denoted 'advanced customer profitability analyses'. Table 6 presents the descriptive statistics and correlation coefficients regarding the methods that are included in the remaining analyses.

Table 6 Customer profitability analyses included in the regression models - descriptive statistics and correlation coefficients $(\mathrm{n}=171)$

\begin{tabular}{|c|c|c|c|c|c|c|c|c|c|}
\hline \multicolumn{2}{|c|}{ Variable } & \multirow{2}{*}{$\frac{\text { Mean }}{4.41}$} & \multirow{2}{*}{$\begin{array}{c}S D \\
1.58\end{array}$} & \multirow{2}{*}{$\frac{\text { Skewness }}{-.19}$} & \multirow{2}{*}{$\begin{array}{c}\text { Kurtosis } \\
-.87\end{array}$} & \multirow{2}{*}{$\begin{array}{c}T A \\
1.00\end{array}$} & \multirow[t]{2}{*}{1} & \multirow[t]{2}{*}{2} & \multirow[t]{2}{*}{3} \\
\hline TA & $\begin{array}{l}\text { Based on a total } \\
\text { appraisement }\end{array}$ & & & & & & & & \\
\hline 1 & $\begin{array}{l}\text { Individual customer } \\
\text { profitability analyses }\end{array}$ & 4.16 & 1.97 & -.18 & -1.20 & $.61 * * *$ & 1.00 & & \\
\hline 2 & $\begin{array}{l}\text { Profitability analyses of } \\
\text { customer segments }\end{array}$ & 4.50 & 1.72 & -.40 & -.79 & $.59 * * *$ & $.31 * * *$ & 1.00 & \\
\hline 3 & $\begin{array}{l}\text { Advanced customer } \\
\text { profitability analyses }\end{array}$ & 2.31 & 1.25 & .73 & -.38 & $.21 * *$ & $.31 * * *$ & .14 & 1.00 \\
\hline
\end{tabular}

Note: $* * * \mathrm{p}<.001 ; * * \mathrm{p}<.01$.

\subsection{Relationships between customer profitability analyses and business performance}

In order to test the formulated hypotheses, two regression analyses (OLS) were carried out, first at the overall level and next at the method level. Table 7 presents the main findings of the regression analyses. Revenues and respondent categories are included in the two models as control variables; the respondent category as a dummy variable $(\mathrm{CFO}=1$ and other respondents $=0)$.

Table 7 Relationships between customer profitability analyses and business performance two regression models $(\mathrm{n}=170)$

\begin{tabular}{lcc}
\hline & $b$ & $t$ \\
\hline Model 1 & .33 & 1.13 \\
Constant & .13 & $2.47^{*}$ \\
Based on a total appraisal & .01 & 1.18 \\
Revenues last year & -.35 & -1.86 \\
CFO & & \\
Model 2 & .55 & 1.84 \\
Constant & .11 & $2.47^{*}$ \\
Individual customer profitability analyses & -.03 & -.57 \\
Profitability analyses of customer segments & .01 & .07 \\
Advanced customer profitability analyses & .01 & 1.43 \\
Revenues last year & -.37 & -1.94 \\
CFO & & \\
\hline
\end{tabular}

Note: $* \mathrm{p}<.05$. 
At the overall level, the extent of use of customer profitability analyses is found to be positively linked to business performance:

- $\quad$ Model 1

Business performance $=(33+.13 *$ extent of use of CPA based on a total appraisal

$$
+0.01 * \text { revenue last year }-.35 * \mathrm{CFO} \text { ) }
$$

The coefficient estimates show that revenues and respondent categories are not significant drivers of business performance. However, the coefficient estimate of the 'extent of use of CPA on a total appraisal' is significant $(\mathrm{p}<0.05)$. The Kolmogorov-Smirnov statistic obtained a value of $0.06(p=.20)$, implying that one cannot say that the residual was not normally distributed. Statistics regarding collinearity and outliers were also found to be satisfactory. The model is significant at the 0.01 level $(\mathrm{F}=4.36)$, however, variations in the extent of use of customer profitability analyses explain only about $6 \%$ of the variations of business performance $\left(\mathrm{R}_{\text {adj }}^{2}=0.06\right)$.

- $\quad$ Model 2

Business performance $=(.55+.11 *$ individual $\mathrm{CPA}-.03 * \mathrm{CPA}$ of customer segments $+.01 *$ advanced $\mathrm{CPA}+.01 *$ revenues last year $-.37 * \mathrm{CFO})$

In model 2, customer profitability analyses of individual customers are the only CAP-method that significantly drives business performance $(p<0.05)$. Thus, the coefficient estimates of the two other methods included (profitability analyses of customer segments and advanced customer profitability analyses) are not significant. In addition, revenues and respondent categories are not significant drivers of business performance. The Kolmogorov-Smirnov statistic obtained a value of 0.06 $(p=.20)$, implying that one cannot say that the residual was not normally distributed. Other relevant statistics are also satisfactory. The model is significant at the 0.05 level $(\mathrm{F}=2.69)$; however, variations in the extent of use of customer profitability analyses explain only about $5 \%$ of the variations of business performance $\left(\mathrm{R}_{\mathrm{adj}}^{2}=0.05\right)$.

Checks for robustness were carried out by analysing the relationships by using factor scores instead of summated scales, both as a dependent variable and as an independent variable ('advanced CPA'). For both models, the findings of the additional regression analyses were concurrent with the findings presented above.

\section{Discussions and conclusions}

The purpose of this paper is to study the relationships between the extents of use of customer profitability analyses and business performance. Based on a literature review, five CPA-methods are included:

1 profitability analyses of individual customers

2 profitability analyses of customer segments 
3 assessments of CLV

4 valuations of customers

5 customers as investments.

In addition, customer profitability analyses as an overall construct is included. Thus, the paper addresses two levels, first an overall level and next the CAP-method level. Based on a literature review and former studies two hypotheses are offered. The context is large Norwegian companies taken from a register that each year gives an overview of the 500 largest Norwegian companies. Four hundred and thirty-seven companies were invited to answer a questionnaire, of which 171 participated; a response rate of about $39 \%$. A comparison of the sample with the sample frame based on NACE (the Statistical Classification of Economic Activities in the European Community) shows that the composition of the sample largely corresponds with the composition of the sample frame. Thus, one cannot assert that the sample is not representative of the sample frame (population).

Regarding the extent of use of customer profitability analyses, the findings of this study indicate that customer segment profitability analyses are more used than customer profitability analyses of individual customers. The remaining three methods (CLV analyses, customer valuation and customers as investments) seem to be less used than customer profitability analyses of individual customers.

A closer look at the five CPA-methods reveals that three of the methods appear to be closely related, i.e., assessments of CLV, valuations of customers and customers as investments. Correlation and factor analyses indicate that the respondents look upon the three approaches as variations of one method. Thus, a new variable is established as a summated scale of the three variables. This new variable is denoted 'advanced customer profitability analyses'. According to this result, customer profitability analyses may be divided into three methods:

1 profitability analyses of individual customers

2 profitability analyses of customer segments

3 advanced customer profitability analyses.

The first approach (profitability analyses of individual customers) is based on detailed information of individual customers (customer accounts). This is a bottom-up approach that is time-consuming and probably expensive, but may give detailed insight for decision-making. The second method is usually a top-down approach, implying that revenues and costs are assigned to various customer segments. Thus, the profitability object is now the individual customer segment or the group of customers and not the individual customer. Segment figures may be rather easy to obtain; however, when indirect costs (fixed costs) represent a large proportion of the total costs, a top-down approach may result in unreliable cost allocation to the customer segments. The third method (advanced customer profitability analyses) embraces the different financial analyses that may be carried out, based on the findings of the two former methods or based on 'forward-looking' figures, i.e., figures that are not closely linked to the bookkeeping system. The estimations of customer profits may include externalities, may be risk-adjusted and consider both the history and the future. Thus, these three methods 
could be considered to cover the various approaches or methods regarding customer profitability analyses.

The findings indicate that the extent of use of customer profitability analyses at the overall level is positively linked to business performance. This regression model (model 1) is significant at the 0.01 level; however, variations in the extent of use of customer profitability analyses explain only $6 \%$ of the variations of business performance. At the method level, three approaches were included in the regression model, i.e.:

1 profitability analyses of individual customers

2 profitability analyses of customer segments

3 advanced customer profitability analyses.

This model (model 2) is significant at the 0.05 level; however, variations in the extent of use of customer profitability analyses explain only $5 \%$ of the variations in business performance. Customer profitability analyses of individual customers are the only significant independent variable of the regression model. Thus, the two other methods (profitability analyses of customer segments and advanced customer profitability analyses) are not significant. In both models, revenues ('business sizes') and respondent category are not significant drivers of business performance.

The findings support the first hypothesis, i.e.:

H1 Overall, there is a positive relationship between the extents of use of holistic customer profitability analyses and business performance.

The findings indicate that increased efforts with respect to 'accounting practices that give additional insight into profit, sales or present value earnings relating to a customer or group of customers' result in increased business performance. Regarding the second hypothesis, only one of the five sub-hypotheses is supported, i.e.:

$\mathrm{H} 2 \mathrm{a}$ The use of profitability analyses as seen in

a the customer profitability analyses of individual customers, is positively related to business performance.

According to model 2, the correlation between the variables 'customer segment profitability analyses' and 'business performance' is negative, however not significant. The correlation between 'advanced customer profitability analyses' and 'business performance' is positive, although not significant. This concept 'represents' the three remaining hypotheses. Thus, the findings regarding model 2 of this study support the findings of Al-Mawali et al. (2012), implying that the method denoted customer profitability analyses of individual customers is the only method that is significantly related to business performance.

As long as the findings indicate that the use of customer profitability analyses (CAP) results in increased business performance, this managerial accounting tool should be of interest to business managers. With respect to CAP-methods, customer profitability analyses of individual customers seem to be the best alternative. The findings indicate that detailed customer accounts of individual customers give support for decisions that result in increased business performance. When detailed customer accounts are available, 
customer segment reports may easily be established. As long as a bottom-up approach is used to establish the customer segment figures, the reports should be much more reliable than reports based on a top-down approach. A customer-base may be segmented in various ways (Zeithaml et al., 2001; Helgesen, 2006; Kotler and Keller, 2016). The information included in the data warehouse of the business unit is decisive for the options that are available regarding the segmentation of the customer-base.

Next, forward-looking managerial tools such as budgets may be included as part of the management accounting system. By establishing budgets for each of the customer accounts, financial goals with respect to volume, revenues, profits, etc. are set for the coming time-period at the individual customer level. In this way, managers and marketers know exactly the targets they are supposed to achieve during the upcoming periods of time. An extension of these individual customer account budgets could be the calculation of the CLV of each of the customers as well as the estimation of the financial value of the whole customer-base. By including externalities (or indirect value drivers) customer valuation may be included as part of the managerial accounting system. By combining historical accounts for several periods of time with forward-looking estimates of financial figures, decision makers should have available the necessary information for managing customer relationships at a profit. It should be underscored that industries and businesses differ with respect to context and complexity. Thus, the use and the perceived merit may differ regarding the five methods addressed in this paper. Some industries may be more forward-looking than other industries (e.g., financial institutions), implying that the three methods denoted 'advanced customer profitability analyses' may be more useful in some industries than in others. It should be remembered that too much information at the same time can make the decision process inefficient. A useful approach could be to give decision makers an overview as well as the opportunity to go to the necessary details, i.e., a kind of drilldown procedure in the database of the business unit.

It should be underscored that the study has a number of limitations. Implicitly, these shortcomings suggest topic areas for further research. Even if all the five customer profitability analyses are described and defined in the questionnaire, the findings indicate that the respondents have problems distinguishing between the three forward-looking customer profitability methods. Instead of asking directly about the level of use of each of the five methods, statements regarding different decision situations could have been applied; say four statements regarding each of the five methods and for the holistic notion of CPA. The study could also include items regarding various adjacent concepts. Such an approach is useful for validation purposes. In addition, the study could employ different dependent variables, cf. the four measurement approaches addressed above (see Section 2.1).

The results show that the variations in the independent variables only explain 5\%-6\% of the variations of the dependent variable. Thus, models that also include the level of use of other managerial accounting tools could have been included in such studies. In this way, the study controls for the effects of the additional explanatory variables. It should be mentioned that the inclusion of additional variables may reduce the effects of the original independent variables; however, that is not always the findings (see, e.g., Helgesen and Nesset, 2010).

This study is based on a survey of large companies, as is the work of Al-Mawali et al. (2012). Similar studies are highly recommended, analysing not only large companies, but also small and medium sized companies owing to the fact that costs to furnish detailed 
customer profitability accounts may be relatively higher for such companies (see, e.g., Neely et al., 1995). Studies may also include cost assignments. However, the assignments of costs are not straightforward (Atkinson et al., 2012; Horngren et al., 2012; Brierley, 2013, 2015; Kraus et al., 2015; Datar and Rajan, 2018). Costs may be estimated by different costing methods:

1 full costing

2 variable costing

$3 \mathrm{ABC}$

4 TDABC.

Combinations of costing methods and customer profitability analyses methods and their relationships to business performance may give additional insight. For instance, is TDABC combined with customer profitability analyses at the individual customer level positively related to business performance?

The main purpose of this paper is to study the relationships between the extents of use of customer profitability analyses and business performance both at the overall level and at the CAP-method level, formulated as the following research question: do customer profitability analyses pay? The conclusion seems to be that the extent of use of customer profitability analyses at the overall level is positively and significantly linked to business performance. At the CAP-method level, the extent of use of customer profitability analyses of individual customers is the only method that is positively and significantly linked to business performance. The findings tell us that only by doing detailed analyses using a bottom up approach does CPA seem to have an influence on business performance. Thus, CPA seems to pay, but not for every approach.

\section{References}

Al-Mawali, H., Zainuddin, Y. and Ali, N.K. (2012) 'Customer accounting information usage and organizational performance', Business Strategy Series, Vol. 13, No. 5, pp.215-223.

Atkinson, A.A., Kaplan, R.S., Matsumura, E.M. and Young, S.M. (2012) Management Accounting: Information for Decision Making and Strategy Execution, 6th ed., Pearson Education Ltd., Harlow, England.

Baines, A. and Langfield-Smith, K. (2003) 'Antecedents to management accounting change: a structural equation approach', Accounting, Organizations and Society, Vol. 28, Nos. 7/8, pp.675-698.

Berger, P.D. and Nasr, N.I. (1998) 'Customer lifetime value: marketing models and applications', Journal of Interactive Marketing, Vol. 12, No. 1, pp.17-30.

Bjørnenak, T. (2013) 'Management accounting tools in banks: are banks without budgets more profitable?', in Kaarbøe, K., Gooderham, P. and Nørreklit, H. (Eds.): Managing in Dynamic Business Environment, pp.51-68, Edward Elgar Publishing, Cheltenham, UK.

Bjørnenak, T. and Helgesen, Ø. (2013) 'Customer relations and cost management', in Mitchel, F., Nørreklit, H. and Jakobsen, M. (Eds.): The Routledge Companion to Cost Management, pp.250-266, Routledge, New York, NY.

Brierley, J.A. (2013) 'The uses of product costs in decision making in British manufacturing industry', International Journal of Managerial and Financial Accounting, Vol. 5, No. 3, pp.294-309. 
Brierley, J.A. (2015) 'An examination of the factors influencing the inclusion of non-manufacturing overhead costs in product costs', International Journal of Managerial and Financial Accounting, Vol. 7, No. 2, pp.134-150.

Brodtkorb, K.J. (2014) Does Increased Creditworthiness Lead to Reduced Interest Rates?, Norwegian School of Economics, Bergen, Norway.

Cadez, S. and Guilding C. (2008) 'An exploratory investigation of an integrated contingency model of strategic management accounting', Accounting, Organizations and Society, Vol. 33, Nos. 7/8, pp.836-863.

Capasso, A., Gallucci, C. and Rossi, M. (2015) 'Standing the test of time. Does firm performance improve with age? An analysis of the wine industry', Business History, Vol. 57, No. 7, pp.1037-1053.

Chenhall, R.H. and Langfield-Smith, K. (2007) 'Multiple perspectives of performance measures', European Management Journal, Vol. 25, No. 4, pp.266-282.

Cohen, J.W. (1988) Statistical Power Analysis for the Behavioural Sciences, 2nd ed., Lawrence Erlbaum Associates, Hillesdale, NJ.

Connolly, T. and Ashworth, J.H. (1994) 'Managing customers for profit', Management Accounting, Vol. 72, No. 4, pp.34-39.

Cooper, R. and Kaplan, R.S. (1988) 'Measure cost right - make the right decision', Harvard Business Review, Vol. 66, No. 5, pp.96-103.

Cooper, R. and Kaplan, R.S. (1999) The Design of Cost Management System, 2nd ed., Prentice-Hall, Inc., Englewood Cliffs, NJ.

Datar, S.M. and Rajan, M.N. (2018) Horngren's Cost Accounting. A Managerial Emphasis, 16th ed., Pearson Education, Ltd., Harlow, Essex, England.

Demeere, N., Stouthuysen, K. and Roodhooft, F. (2009) 'Time-driven activity-based costing in an outpatient clinic environment: development, relevance and managerial impact', Health Policy, Vol. 92, No. 2, pp.296-304.

Eccles, R.G. (1991) 'The performance measurement manifesto', Harvard Business Review, Vol. 69, No. 1, pp.131-137.

Egan, J. (2008) Relationship Marketing. Exploring Relational Strategies in Marketing, 3rd ed., Pearson Education, Ltd., Harlow, Essex, England.

Eurostat (2008) NACE Rev. 2: Statistical Classification of Economic Activities in the European Community, Office for Official Publications of the European Communities, Luxembourg.

Everaert, P., Bruggeman, W., Sarens, G., Anderson, S.R. and Levant, Y. (2008) 'Cost modelling in logistics using time-driven ABC: experiences from a wholesaler', International Journal of Physical Distribution \& Logistics Management, Vol. 38, No. 3, pp.172-191.

Farris, P.W., Bendle, N.T., Pfeifer, P.E. and Reibstein, D.J. (2010) Marketing Metrics: The Definitive Guide to Measuring Marketing Performance, Pearson Education, Inc., Upper Saddle River, NJ.

Fish, M., Miller, W., Becker, D.A. and Pernsteiner, A. (2017) 'The role of organizational culture in the adoption of customer profitability analysis: a field study', Qualitative Research in Accounting \& Management, Vol. 14, No. 1, pp.38-59.

Foster, G. and Gupta, M. (1994) 'Marketing, cost management and management accounting', Journal of Management Accounting Research, Fall, Vol. 6, pp.43-73.

Foster, G., Gupta, M. and Sjoblom, L. (1996) 'Customer profitability analysis: challenges and new directions', Journal of Cost Management, Vol. 10, No. 1, pp.5-17.

Giacosa, E., Culasso, F., Mazzoleni, A. and Matteo, R. (2016) 'A model for the evaluation trends performance in small and medium enterprises', Corporate Ownership \& Control, Vol. 13, No. 4, pp.389-402.

Govindarajan, V. (1984) 'Appropriateness of accounting data in performance evaluation: an empirical examination of environmental uncertainty as an intervening variable', Accounting, Organizations and Society, Vol. 9, No. 2, pp.125-135. 
Govindarajan, V. (1988) 'A contingency approach to a strategy implementation at the business-unit level: integrating an administrative mechanism with strategy', Academy of Management Journal, Vol. 31, No. 4, pp.838-853.

Govindarajan, V. and Fisher, J. (1990) 'Strategy, control systems and resource sharing: effects on business-unit performance', Academy of Management Journal, Vol. 33, No. 2, pp.259-285.

Guilding, C. and McManus, L. (2002) 'The incidence, perceived merit and antecedents of customer accounting: an exploratory note', Accounting, Organizations and Society, Vol. 27, Nos. 1/2, pp.45-59.

Gupta, A.K. and Govindarajan, V. (1984) 'Business unit strategy, managerial characteristics, and business unit effectiveness at strategy implementation', Academy of Management Journal, Vol. 27, No. 1, pp.25-41.

Gupta, S. and Lehmann, D.R. (2005) Managing Customers as Investments. The Strategic Value of Customers in the Long Run, Wharton School Publishing, Pearson Education, Ltd., Upper Saddle River, NJ.

Havelin, G.G., Helsem, A.E. and Helgesen, Ø. (2013) 'Bruk og nytte av kundelønnsomhetsanalyser i store norske foretak', Magma, Vol. 16, No. 4, pp.38-49.

Helgesen, Ø. (1999) Kundelønnsomhet, Norwegian School of Economics and Business Administration, Bergen, Norway.

Helgesen, Ø. (2006) 'Customer segments based on customer account profitability', Journal of Targeting, Measurement and Analysis for Marketing, Vol. 14, No. 3, pp.225-237.

Helgesen, Ø. (2007) 'Customer accounting and customer profitability analysis for the order handling industry - a managerial accounting approach', Industrial Marketing Management, Vol. 36, No. 6, pp.757-769.

Helgesen, Ø. (2008) 'Targeting customers: a financial approach based on creditworthiness', Journal of Targeting, Measurement and Analysis for Marketing, Vol. 16, No. 4, pp.261-273.

Helgesen, Ø. and Nesset, E. (2010) 'Gender, store satisfaction and antecedents: a case study of a grocery store', Journal of Consumer Marketing, Vol. 27, No. 2, pp.114-126.

Helm, S. and Salminen, R.T. (2010) 'Basking in reflected glory: using customer reference relationships to build reputation in industrial markets', Industrial Marketing Management, Vol. 39, No. 6, pp.737-743.

Holm, M., Kumar, V. and Rohde, C. (2012) 'Measuring customer profitability in complex environments: an interdisciplinary contingency framework', Journal of the Academy of Marketing Science, Vol. 40, No. 3, pp.387-401.

Horngren, C.T., Datar, S.M. and Rajan, M.V. (2012) Cost Accounting. A Managerial Emphasis, 14th ed., Pearson Education, Ltd., Harlow, Essex, England.

Howell, R.A. and Soucy, S.R. (1990) 'Customer profitability: as critical as product profitability', Management Accounting, Vol. 72, No. 4, pp.43-47.

Irvine, P.J., Park, S.S. and Yildizhan, C. (2016) 'Customer-based concentration, profitability, and the relationship life cycle', The Accounting Review, Vol. 91, No. 3, pp.883-906.

Jalkala, A. and Salmimen, R.T. (2010) 'Practices and functions of customer reference marketing leveraging customer references as marketing assets', Industrial Marketing Management, Vol. 39, No. 6, pp.975-985.

Kaplan, R.S. and Anderson, S.R. (2004) 'Time-driven activity-based costing', Harvard Business Review, Vol. 82, No. 11, pp.131-138.

Kaplan, R.S. and Anderson, S.R. (2007) Time-driven Activity-based Costing: A Simpler and More Powerful Path to Higher Profits, Harvard Business School Press, Boston, MA.

Kaplan, R.S. and Norton, D.P. (2004) Strategy Maps: Converting Intangible Assets into Tangible Outcomes, Harvard Business School Press, Boston, MA.

Kirby, J. (2005) 'Toward a theory of high performance', Harvard Business Review, Vol. 83, No. 7, pp.30-39. 
Kotler, P. and Keller, K.L. (2016) Marketing Management, 15th ed., Global ed., Pearson Education, Ltd., Harlow, Essex, England.

Kraus, K. Håkansson, H. and Lind, J. (2015) 'The marketing-accounting interface - problems and opportunities', Industrial Marketing Management, Vol. 46, No. 6, pp.3-10.

Krishnan, A. and Ramasamy, R. (2011) 'The key financial and non-financial performance measures of manufacturing firms in Malaysia', International Journal of Managerial and Financial Accounting, Vol. 3, No. 4, pp.403-417.

Kumar, V. (2008) Managing Customers for Profit. Strategies to Increase Profits and Build Loyalty, Pearson Education, Inc., Upper Saddle River, NJ.

Kumar, V. (2018) 'A theory of customer valuation: concepts, metrics, strategy, and implementation', Journal of Marketing, Vol. 82, No. 1, pp.1-19.

Lind, J. and Strømsten, T. (2006) 'When do firms use different types of customer accounting?' Journal of Business Research, Vol. 59, No. 12, pp.1257-1266.

Lord, B.R., Shanahan, Y.P. and Nolan, B.M. (2007) 'The use and perceived merit of customer accounting in New Zealand', Accounting Research Journal, Vol. 20, No. 1, pp.47-59.

Malmi, T., Raulas, M., Gundergan, S. and Sehm, J. (2004) 'An empirical study on customer profitability accounting, customer orientation and business unit performance', Paper presented on the 4th Conference on New Directions in Management Accounting: Innovations in Practice and Research [online] http://wwwdocs.fce.unsw.edu.au/accounting/news/seminars2004_s2/ paper06.pdf.

March, J.G. and Sutton, R.I. (1997) 'Organizational performance as a dependent variable', Organization Science, Vol. 8, No. 6, pp.698-706.

McManus, L. (2013) 'Customer accounting and marketing performance measures in the hotel industry: evidence from Australia', International Journal of Hospitality Management, Vol. 33, No. 1, pp.140-152.

McManus, L. and Guilding, C. (2008) 'Exploring the potential of customer accounting: a synthesis of the accounting and marketing literatures', Journal of Marketing Management, Vol. 24, Nos. 7/8, pp.771-795.

Neely, A. and Adams, C. (2002) Performance Prism: The Scorecard for Measuring and Managing Stakeholder Relationships, Financial Times/Prentice Hall, London, UK.

Neely, A., Gregory, M. and Platts, K. (1995) 'Performance measurement system design. A literature review and research agenda', International Journal of Operations \& Production Management, Vol. 15, No. 4, pp.80-116.

Nenonen, S. and Storbacka, K. (2016) 'Driving shareholder value with customer asset management: moving beyond customer lifetime value', Industrial Marketing Management, January, Vol. 52, No. 1, pp.140-150 [online] https://doi.org/10.1016/j.indmarman.2015. 05.019 .

Niraj, R., Gupta, M. and Narasimhan, C. (2001) 'Customer profitability in a supply chain', Journal of Marketing, Vol. 65, No. 3, pp.1-16.

Noone, B. and Griffin, P. (1999) 'Managing the long-term profit yield from market segments in a hotel environment: a case study on the implementation of customer profitability analysis', International Journal of Hospitability Management, Vol. 18, No. 2, pp.111-128.

Pollanen, R.M. and Abdel-Maksoud, A.B. (2010) 'The deployment of contemporary management accounting practices in Canadian firms: a contingency approach', International Journal of Managerial and Financial Accounting, Vol. 2, No. 2, pp.134-152.

Reichheld, F. (1996) The Loyalty Effect: The Hidden Force behind Growth, Profits, and Lasting Value, Harvard Business School Press, Bain \& Company, Inc., Boston, MA.

Reinartz, W.J. and Kumar, V. (2000) 'On the profitability of long-life customers in a noncontractual setting: an empirical investigation and implications for marketing', Journal of Marketing, Vol. 64, No. 4, pp.17-35.

Reinartz, W.J., Thomas, J.S. and Kumar, V. (2005) 'Balancing acquisition and retention resources to maximize customer profitability', Journal of Marketing, Vol. 69, No. 4, pp.63-79. 
Richard, P.J., Devinney, T.M., Yip, G.S. and Johnson, G. (2009) 'Measuring organizational performance: towards methodological best practice', Journal of Management, Vol. 35, No. 3, pp.718-804.

Rickards, R.C. and Ritsert, R. (2018) 'Organisational influences on management accounting toolkits in Chinese enterprises: an exploratory study', International Journal of Managerial and Financial Accounting, Vol. 10, No. 1, pp.16-31.

Rust, R.T., Kumar, V. and Venkatesan, R. (2011) 'Will the frog change into a prince? Predicting future customer profitability', International Journal of Research in Marketing, Vol. 28, No. 4, pp.281-294.

Rust, R.T., Zeithaml, V.A. and Lemon, K.N. (2000) Driving Customer Equity. How Customer Lifetime Value is Reshaping Corporate Strategy, The Free Press, New York, NY.

Ryals, L. (2008) Managing Customers Profitably, John Wiley \& Sons Ltd., Chichester, West Sussex, England.

Silvi, R., Bartoloni, M., Raffoni, A. and Visani, F. (2015) 'The practice of strategic performance measurement systems: models, drivers and information effectiveness', International Journal of Productivity and Performance Management, Vol. 64, No. 2, pp.194-227.

Storbacka, K. (1995) The Nature of Customer Relationship Profitability. Analysis of Relationships and Customer Bases in Retail Banking, Svenska Handelshøgskolan, Helsingfors, Finland.

Tanima, F.A. and Bates, K. (2015) 'The incidence and perceived managerial merit of customer accounting in New Zealand', Pacific Accounting Review, Vol. 27, No. 4, pp.466-485.

van Raaij, E.M. (2005) 'The strategic value of customer profitability analysis', Marketing Intelligence \& Planning, Vol. 23, No. 4, pp.372-381.

van Raaij, E.M., Vernooij, M.J.A. and van Triest, S. (2003) 'The implementation of customer profitability analysis: a case study', Industrial Marketing Management, Vol. 32, No. 7, pp.573-583.

Varadarajan, P.R. and Ramanujam, V. (1990) 'The corporate performance conundrum: a synthesis of contemporary views and an extension', Journal of Management Studies, Vol. 27, No. 5, pp.463-483.

Venkatraman, N. and Ramanujam, V. (1986) 'Measurement of business performance in strategy research: a comparison of approaches', Academy of Management Review, Vol. 11, No. 4, pp.801-814.

Vigolo, V., Bonfanti, A., Magliocca, P. and Kirakosyan, K. (2016) 'Corporate culture and firm performance', International Journal of Managerial and Financial Accounting, Vol. 8, No. 2, pp.109-123.

Vij, S. and Bedi, H.S. (2016) 'Are subjective business performance measures justified?', International Journal of Productivity and Performance Management, Vol. 65, No. 5, pp.603-621.

Weir, K. (2008) 'Examining the theoretical influences of customer valuation metrics', Journal of Marketing Management, Vol. 27, Nos. 7/8, pp.797-824.

Zeithaml, V.A., Rust, R.T. and Lemon, K.N. (2001) 'The customer pyramid: creating and serving profitable customers', California Management Review, Vol. 43, No. 4, pp.118-142. 